\title{
Front Matter: Volume 11540
}

, "Front Matter: Volume 11540," Proc. SPIE 11540, Emerging Imaging and Sensing Technologies for Security and Defence V; and Advanced Manufacturing Technologies for Micro- and Nanosystems in Security and Defence III, 1154001 (14 October 2020); doi: 10.1117/12.2584643 


\title{
PROCEEDINGS OF SPIE
}

\section{Emerging Imaging and Sensing Technologies for Security and Defence V; and Advanced Manufacturing Technologies for Micro- and Nanosystems in Security and Defence III}

\author{
Gerald S. Buller \\ Richard C. Hollins \\ Robert A. Lamb \\ Martin Laurenzis \\ Andrea Camposeo \\ Maria Farsari \\ Luana Persano \\ Lynda E. Busse \\ Editors
}

21-25 September 2020

Online Only, United Kingdom

Sponsored by

SPIE

Cooperating Organisations

European Optical Society • KTN-Knowledge Transfer Network (United Kingdom) • Technology Scotland (United Kingdom) • Visit Scotland (United Kingdom) • BARSC-British Association of Remote Sensing (United Kingdom) • EARSeL_European Association of Remote Sensing Laboratories (Germany) ISPRSInternational Society for Photogrammetry and Remote Sensing

Published by

SPIE

Volume 11540 
The papers in this volume were part of the technical conference cited on the cover and title page. Papers were selected and subject to review by the editors and conference program committee. Some conference presentations may not be available for publication. Additional papers and presentation recordings may be available online in the SPIE Digital Library at SPIEDigitallibrary.org.

The papers reflect the work and thoughts of the authors and are published herein as submitted. The publisher is not responsible for the validity of the information or for any outcomes resulting from reliance thereon.

Please use the following format to cite material from these proceedings:

Author(s), "Title of Paper," in Emerging Imaging and Sensing Technologies for Security and Defence $V ;$ and Advanced Manufacturing Technologies for Micro- and Nanosystems in Security and Defence III, edited by Gerald S. Buller, Richard C. Hollins, Robert A. Lamb, Martin Laurenzis, Andrea Camposeo, Maria Farsari, Luana Persano, Lynda E. Busse, Proceedings of SPIE Vol. 11540

(SPIE, Bellingham, WA, 2020) Seven-digit Article CID Number.

ISSN: 0277-786X

ISSN: 1996-756X (electronic)

ISBN: 9781510638938

ISBN: 9781510638945 (electronic)

Published by

SPIE

P.O. Box 10, Bellingham, Washington 98227-0010 USA

Telephone +1 3606763290 (Pacific Time) · Fax + 13606471445

SPIE.org

Copyright @ 2020, Society of Photo-Optical Instrumentation Engineers.

Copying of material in this book for internal or personal use, or for the internal or personal use of specific clients, beyond the fair use provisions granted by the U.S. Copyright Law is authorized by SPIE subject to payment of copying fees. The Transactional Reporting Service base fee for this volume is $\$ 21.00$ per article (or portion thereof), which should be paid directly to the Copyright Clearance Center (CCC), 222 Rosewood Drive, Danvers, MA 01923. Payment may also be made electronically through CCC Online at copyright.com. Other copying for republication, resale, advertising or promotion, or any form of systematic or multiple reproduction of any material in this book is prohibited except with permission in writing from the publisher. The CCC fee code is 0277 $786 \mathrm{X} / 20 / \$ 21.00$.

Printed in the United States of America by Curran Associates, Inc., under license from SPIE.

Publication of record for individual papers is online in the SPIE Digital Library.

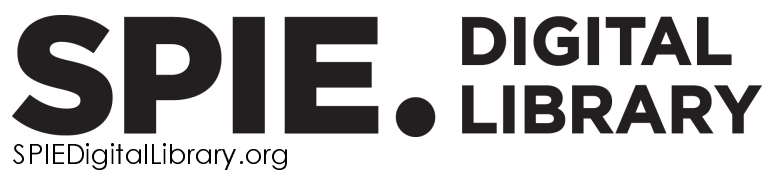

Paper Numbering: Proceedings of SPIE follow an e-First publication model. A unique citation identifier (CID) number is assigned to each article at the time of publication. Utilization of CIDs allows articles to be fully citable as soon as they are published online, and connects the same identifier to all online and print versions of the publication. SPIE uses a seven-digit CID article numbering system structured as follows:

- The first five digits correspond to the SPIE volume number.

- The last two digits indicate publication order within the volume using a Base 36 numbering system employing both numerals and letters. These two-number sets start with 00, 01, 02, 03, 04, 05, 06, 07, 08, 09, OA, OB ... OZ, followed by 10-1Z, 20-2Z, etc. The CID Number appears on each page of the manuscript. 


\section{Contents}

QUANTUM COMMUNICATIONS

1154005 The EPSRC quantum communications hub (Invited Paper) [1 1540-1]

1154006 Prospects of time-bin quantum key distribution in turbulent free-space channels [1 1540-2]

1154007 Link loss analysis for a satellite quantum communication down-link [1 1540-3]

1154008 A practical hybrid quantum-safe cryptographic scheme between data centers [11540-4]

QUANTUM SENSING I

11540 OC Advances in GaN laser diodes for quantum sensors and optical atomic clocks [1 1540-8]

QUANTUM SENSING II

11540 OF Including the vacuum in the post-selected model of quantum illumination (Invited Paper) [11540-11]

\section{ADVANCED IMAGING}

11540 OG Turbulence mitigation in neuromorphic camera imagery (Invited Paper) [1 1540-12]

$11540 \mathrm{OH} \quad$ Performance assessment of reconstruction algorithms for compressed sensing threat detection applications [11540-13]

11540 0J Imaging from temporal data via spiking convolutional neural networks [11540-15]

\section{QUANTUM ENHANCED IMAGING I}

11540 OP Photon counting 3D imaging from multiple positions (Invited Paper) [1 1540-21] 
QUANTUM ENHANCED IMAGING II

11540 OU Investigation of some limitations of non-line-of-sight scene reconstruction [1 1540-26]

\section{EMERGING TECHNOLOGIES}

11540 OV Neuromorphic technologies for defence and security (Invited Paper) [1 1540-27]

11540 OW Stress induced birefringence of glass-to-metal bonded components [1 1540-28]

11540 0X Voltammetry as a rapid screening method for NPS identification [1 1540-29]

ADVANCED COMMUNICATION AND MANUFACTURING

11540 OY Secrecy capacity of Lifi systems (Invited Paper) [1 1540-30]

3D PRINTING AND AUTONOMOUS SYSTEMS

1154014 A new method for the precise determination of rational geometric parameters of the helical groove and cutting part of high-performance tri-flute [1 1540-36]

1154015 Memory-centric approach and human-like technologies in the design of automated technological complexes for advanced manufacturing [1 1540-37]

OPTICAL MATERIALS AND BIOMATERIALS IN SECURITY AND DEFENCE SYSTEMS TECHNOLOGY

$1154017 \quad$ Multilayer structures with an azo layer (Invited Paper) [11540-41]

POSTER SESSION

11540 1D Development of object-based change detection method in restricted areas using GIS thematic data [1 1540-47]

$115401 \mathrm{E} \quad$ High-precision method for determining the optimal trajectory of movement of a conical grinding wheel relative to the helical groove of solid ceramic mills [1 1540-48]

1154016 A new method for modeling edges of a toroidal cutting surface of solid ceramic end mills [1 1540-50] 